\title{
Performing freedom in the Dutch deportation regime: bureaucratic persuasion and the enforcement of 'voluntary return'
}

\section{Laura Cleton \& Sébastien Chauvin}

To cite this article: Laura Cleton \& Sébastien Chauvin (2019): Performing freedom in the Dutch deportation regime: bureaucratic persuasion and the enforcement of 'voluntary return', Journal of Ethnic and Migration Studies, DOI: 10.1080/1369183X.2019.1593819

To link to this article: https://doi.org/10.1080/1369183X.2019.1593819

曲 Published online: 25 Mar 2019.

Submit your article to this journal ๘

Џ Article views: 45

View Crossmark data $\complement$ 


\title{
Performing freedom in the Dutch deportation regime: bureaucratic persuasion and the enforcement of 'voluntary return'
}

\author{
Laura Cleton $^{\mathrm{a}}$ and Sébastien Chauvin ${ }^{\mathrm{b}}$ \\ ${ }^{a}$ Department of Political Science, University of Antwerp, Antwerp, Belgium; ${ }^{\mathrm{b}}$ Institute for Social Science, \\ University of Lausanne, Switzerland
}

\begin{abstract}
How do states relate to undocumented immigrants and asylum seekers once they have been formally rejected? A growing amount of research has been devoted to the role of government and NGO workers in executing soft-deportation policy through 'voluntary return' programmes. Many of these studies convincingly argue that voluntary return most often is anything but voluntary. However, less effort has been spent answering the question of why, then, departure is still constructed as voluntary and how this construction is realised in practice. This paper explores the work of street-level bureaucrats in charge of expelling unauthorised immigrants from the Netherlands in case expulsion cannot stem from the law alone and deportation workers deploy extra-legal strategies to carry out exclusionary policy goals. In these cases, we show that, in addition to building trust relationships with migrants, government and NGO workers ostensibly emphasise their clients' self-determination and agency. By examining the performative construction of 'voluntariness' in highly asymmetrical interview rituals, this article brings attention to an under-theorised condition of the conduct of conduct in the era of governmentality: if modern bureaucratic power, however punitive, must govern primarily by addressing the freedom of free agents, then it must ensure the interpretation of conduct as voluntary.
\end{abstract}

\section{ARTICLE HISTORY}

Received 6 August 2018

Accepted 6 March 2019

\section{KEYWORDS}

Governmentality; agency; street-level bureaucracy; voluntary return; deportability

\section{Introduction}

Government treatment of rejected asylum seekers and undocumented immigrants in the context of return policy has become a major point of contention in European political conflicts over international migration. At the peak of the so-called 'refugee crisis', in 2015-2016, approximately 93,000 immigrants applied for asylum in the Netherlands. Forty-four per cent received a negative decision on their request (Ministerie van Veiligheid en Justitie 2017). However, over the course of 2016 it became clear that most of those who did not qualify for asylum and were not found eligible to stay in the Netherlands nevertheless would not immediately return to their countries of origin. In April 2017, the Repatriation and Departure Service (DT\&V) recorded forty-seven per cent of their 'clients' as 
having 'left without supervision'. In practice, this meant that they either had left the Netherlands independently or continued to reside in the country without authorisation.

Should they come into contact with authorities again, these rejected immigrants are subject to deportation. However, the latter cannot always be effectively enforced, either because it is legally ruled out by international treaties, or because it is technically impossible. In those cases, the only remaining option that bureaucrats enforcing migration policy have at their disposal is seeking to persuade rejected migrants to 'depart voluntarily' (Gibney 2008; Webber 2011; Collyer 2012). This article addresses the work of DT\&V government workers and Dutch NGOs who arrange 'voluntary return' and provide migrants with legal counselling. As street-level bureaucrats who are responsible for 'delivering benefits and sanctions and structuring and delimiting people's lives and opportunities' (Lipsky $1980,4)$, return officers enjoy a large amount of discretion in dealing with legally precarious migrants (Van der Leun 2006). Classic studies of street-level bureaucracies typically depict cases in which state agents hold the power to apply the law in a flexible way or decide not to apply it in order to fulfil broader policy goals, reflecting a 'consistent mode of governance in which discretion and leeway accorded to street-level bureaucrats are necessary for the state to exert power over citizens' behaviour' (Dubois 2014, 40). In the case presented here, the law is applied to its full extent but is experienced as insufficient to meet the exclusionary policy objectives assigned to migration bureaucrats. Indeed, DT\&V civil servants charged with expelling unauthorised migrants and rejected asylum seekers soon discover that formal law only enables them to remove a small minority of people categorised as deportable. As an alternative to relying on hard state power, such as using coercion or applying sanctions, their work consists in deploying soft-power techniques (Nye 2004) by building close bonding relationships and foregrounding agentic power and choice to eventually elicit 'voluntary return'. In particular, both government and NGO workers typically present undocumented immigrants with limited options to choose from and ensure that, if and when the departure route is taken, the latter is interpreted by all parties as voluntary.

Many international studies of such programmes convincingly argue that voluntary return most often is anything but voluntary and show that practices follow a coercive logic geared towards compulsory return under the ostensible guise of cooperation (Gibney 2008; Andrijasevic and Walters 2010; Ashutosh and Mountz 2011; Webber 2011; Lietaert 2016; Vandevoordt 2018). Kalir (2017) and Leerkes, van Os, and Boersema (2017) therefore suggested that 'voluntary returns' can be better conceptualised as 'soft deportations'. For Leerkes, van Os, and Boersema $(2017,8)$ the latter term indicates 'that such return has deportation-like properties, while acknowledging that it depends less on force and deterrence' than 'classic' deportations. For Kalir $(2017,57)$, the concept clearly characterises voluntary return programmes as 'an integral part of the overall biopolitical scheme that absolves the territorial removal of illegalised subjects under state sovereignty'. However, what these studies have paid less attention to are the processes through which these coerced practices come to be constituted as 'voluntary' and interpreted by both parties as a result of migrants' own 'agency' and choice.

By examining the construction of 'voluntariness' in these interactions, this article brings attention to an under-theorised condition of the conduct of conduct in the 'new regime of autonomy and choice' described by Nikolas Rose in Powers of Freedom (1999, 89): that if modern bureaucratic power, however punitive, regulates conduct by considering agents as autonomous subjects, this mode of government requires significant ideological work in 
order to ensure the interpretation of conduct as voluntary. As we will show in the case of Dutch return policy, this definition of the situation is enacted via 'rituals of freedom', during which the 'clients' must forcibly perform agency, even though their options are bounded and geared towards return. The frame of 'free choice' does not represent a mere second best for state agents to use when no forcible option is within reach, as a purely instrumentalist explanation would have it. Indeed, official DT\&V policy prescribes a preference for 'voluntary return' over forced removal at any time, including for migrants who would otherwise easily be deported (DT\&V 2015). Although there are obvious budgetary, geopolitical and practical reasons for this (Gibney 2008; Collyer 2012), we will suggest that this state preference for 'freedom' as an interpretive trope of conduct also stems from the broader dynamics of modern governmentality.

Before further analysing government and NGO workers' practices in the context of Dutch migration policy, the following section reviews the literature on street-level bureaucracies and governmentality to emphasise the contemporary role of persuasion and 'free choice' in regulating conduct. Section III presents the legal and geopolitical factors that render certain undocumented immigrants and rejected asylum seekers 'non-deportable' and allow for their continued stay in the Netherlands. This politicaladministrative opportunity structure makes 'voluntary return' the only available option for government and NGO workers seeking to obtain departure and informs the interviews they carry out with migrants. Section IV sets out the policy context through a brief description of the Dutch 'deportation continuum' (Kalir and Wissink 2015), emphasising the twin roles of government agencies and NGOs in executing the country's return policy. Section V and VI present the various strategies that return agents apply to elicit 'voluntary return'. Most of these techniques involve the scripted performance of agency and selfdetermination and seek to ensure that the decision to return 'voluntarily' stems from a shared consensus on 'free choice'.

\section{Bureaucratic persuasion, freedom and the limits of the law}

Inspired by Foucault's foundational lectures (Foucault 2007), governmentality studies have long noted that modern power addresses citizens as free agents having to act in their own interest. Foucault observes

[...] the insertion of freedom within governmentality, not only as the right of individuals legitimately opposed to the power, usurpations, and abuses of the sovereign or the government, but as an element that has become indispensable to governmentality itself. Henceforth, a condition of governing well is that freedom, or certain forms of freedom, are really respected. Failing to respect freedom is not only an abuse of rights with regard to the law, it is above all ignorance of how to govern properly. The integration of freedom, and the specific limits [proper to $]^{1}$ this freedom within the field of governmental practice has now become an imperative (Foucault 2007, 451, emphases added).

Some authors have argued that while this mode of regulation through freedom is mostly deployed towards citizens, aliens and more precarious denizens are instead primarily the object of mere discipline. According to Rose, for example:

Strategies for the conduct of conduct increasingly operate in terms of two distinct sectors. For the majority, expertise operated in terms of the logic of choice, transforming the ways 
through which individuals come to think of themselves, through inculcating desires of selfdevelopment. [...] Yet a minority remain outside this regime of civility (Rose 1999, 88).

For his part, Jonathan Inda borrows from Cruishank (1999) the distinction between 'technologies of citizenship' - by which states aim to moralise citizens framed as inherently reformable - and 'anti-citizenship technologies' aimed at illegal residents viewed as incapable of proper self-management' (Inda 2005, 19-22). By contrast, the case study at the heart of this article will show that freedom and self-regulation are also key to how the modern state relates to its legally precarious residents, who thus cannot merely be described as 'anti-citizens' (see Chauvin and Garcés-Mascareñas 2012).

Yet, studies of governmentality have been ambivalent about the status and implications of such 'freedom', which has too often been taken for granted. Foucault himself states that the relation between government and freedom 'is not exactly, fundamentally, or primarily an ideology. First of all and above all it is a technology of power' (Foucault 2007, 71). He called for a physics of power analysing government 'as physical action in the element of nature' that 'can only be carried through and by reliance on the freedom of each'. This naturalisation of freedom as a tool of government potentially opened the way to what could be described as a 'behaviourist' bias in governmentality studies, one that fails to account for the distinctly ideological component of the social construction of freedom as freedom. Rose offers a more ambivalent formulation, by stating that freedom is both a set of practices and an interpretive trope:

The private conduct of free citizens was to be civilized by equipping them with languages and techniques of self-understanding and self-mastery. Freedom thus becomes linked to a norm of civility. [...] These practices governed through freedom, to the extent that they sought to invent the conditions in which subjects themselves would enact the responsibilities that composed their liberties (Rose 1999, 72, emphases added).

Whether the ideal of 'self-mastery' reflects reality or pertains to fiction, understanding agency as agency requires a 'language' and thus ideological work. In contrast to most of the governmentality literature, this article will specifically study the social construction of freedom in the process of governing non-citizens' conduct. In the case of 'voluntary return', undocumented migrants must be persuaded to leave by themselves and convinced that the decision stems from their own choice. This requires the use not of raw force but of incentives that purport to make the desired behaviour objectively sensible and hence interpretable as the product of 'agency'. Rejected migrants must decide to leave 'in their own interest' (Volkskrant, October 30, 2015).

This article also expands the scholarship on bureaucracies and the interaction between street-level bureaucrats (Lipsky 1980) and their 'clients'. Most studies imply that bureaucrats' power stems from their ability to apply the law or not, or to choose between different ways of implementing it, in order to govern the behaviour of their 'clients'. In contrast, this article brings attention to cases when the government of behaviour cannot stem from law or discretion alone and street-level bureaucrats need to deploy 'extra-legal' strategies as a policy instrument on a permanent basis (Fatovic and Kleinerman 2013).

These strategies are well known to scholars studying police interrogations in the United States, where 'third degree' tactics (torture) were officially prohibited following the Wickersham report in 1931. Later, in its 1966 Miranda v. Arizona decision, the Supreme Court established the right to remain silent and the right for suspects to be informed of the 
opportunity to consult with an attorney before and during questioning. In particular, under the Miranda v. Arizona ruling, it was decided that the refusal to confess and incriminate oneself may never itself constitute a punishable offense. Following these civil rights decisions, the recourse to coercive methods by police interrogators to elicit confessions was extensively restricted (Leo 1992; Shuy 1998; Thomas and Leo 2012). Since then, the law has required that a confession be completely voluntarily, or it may be excluded from admission into evidence at trial (Ofshe and Leo 1997). As it is not in a person's interest to admit guilt and as coercive methods of physical force, torture or incommunicado interrogation are no longer legal - although they have by no means disappeared (The Guardian, January 28, 2016) -, interrogators have developed methods of psychological coercion to provoke 'free' confession (Ofshe and Leo 1997). Among others, these softer forms of coercion include the strategic use of persuasion to induce admissions and confessions. The police officer will emphasise the merits of admitting guilt and convince the suspect that it is in his or her own interest to collaborate with authorities (Kassin and McNall 1991; Leo 1992, 1996).

The specific techniques put forward in this example show how street-level bureaucrats make their 'clients' comply when the execution of policy may only stem from voluntary compliance. Taking return policy as a case study, the empirical sections of the paper focus on techniques that Dutch migration bureaucrats deploy in similar situations, when their 'clients' are ordered to leave the Netherlands, but forced removal cannot be carried out and 'voluntary return' programmes appear to civil servants as the only remaining option. The next section first explains under which specific circumstances these 'clients' are rendered 'non-deportable'.

\section{The making of migrant non-deportability}

Nicholas De Genova $(2002,439)$ coined the term deportability to name a universal condition shared by noncitizens, which implies 'the possibility of being removed from the space of the nation-state'. Although any unauthorised immigrant is theoretically subject to expulsion by the state, in practice not everyone can be forcibly relocated to their country of origin. As a consequence, the majority of undocumented immigrants continue to stay within the boundaries of the receiving nation-state, while the Sword of Damocles of deportability hangs over them. Yet, the degree to which undocumented immigrants are produced as practically deportable or non-deportable varies depending on time and space (Paoletti 2010; Rosenberger 2014).

Non-deportability often stems from the reluctance of origin states to cooperate on forced return. Indeed, deportation always requires the willingness of another state to accept the returnee (Gibney 2008). In 2016-2017, when the research for this article took place, several countries such as Morocco, Iraq, Iran and Afghanistan refused to cooperate with the Dutch government on forced removal. In international law, a country is obligated to take its own nationals back. Before that, nationality must be established (Broeders 2010). Often, however, documentation linking an individual to a particular state is not available. Indeed, immigrants in the Netherlands and other receiving countries frequently have recourse to identity stripping, i.e. 'shed[ding] their legal identity to escape the state's reach' (Ellerman 2010, 424), whether by throwing their passports or by erasing their fingerprints and thus physically mutilating themselves. 
In cases where papers or fingerprints have been destroyed, government officials attempt to determine identity through other means. The first way nationality can be established is by presenting the 'client' at embassies of likely countries of origin, where the state consul may or may not decide whether the migrant is a citizen of their country. Thus government officials frequently go 'embassy shopping' in the hope of establishing a migrant's nationality (ibid., 416). If accepted by an embassy, travel documents must then be acquired. For all countries of origin, government workers, NGOs or immigrants themselves must ask for a temporary laissez-passer. For countries reluctant to cooperate on forced removals, embassies often do not issue these documents unless requested by migrants themselves through in-person visits. In some cases, states can circumvent this legal constraint by covertly deporting migrants to countries without a functioning government through crafting the travel document themselves. This substitute travel document, in Dutch the Europees Reisdocument, has made deportations to countries such as Afghanistan and Somalia possible, for example. However, for the vast majority of countries to which unauthorised migrants are repatriated, this indirect option is not available to the Dutch government.

Moreover, there are ways for 'clients' to effectively delay or cancel their deportation procedure from the Netherlands, even if travel documentation is available. Rejected immigrants are often assisted by NGOs in acquiring temporary legal status. Various medical conditions may allow them to claim temporary residency, until they are declared 'fit' for return to their home countries. Amongst others, pregnancy (Castañeda 2008) or severe illness (Ticktin 2006) might result in a temporary Artikel 64 permit and effectively delay the process of deportation from the Netherlands. Immigrants who manage to acquire these temporary residence permits are therefore neither regular nor irregular, but solely documented, 'recognised and tolerated but not legally authorised' (Rosenberger 2014, 8). Likewise, government workers are responsible for checking undocumented immigrants' eligibility for legal procedures protecting victims of human trafficking and other 'exceptional circumstances'. Initiating such a procedure may postpone deportation for up to three years. This is, however, not the case regarding requests for family reunification. During fieldwork, we encountered the situation of an irregularly staying Guinean woman, who was considering such an application with her Dutch boyfriend. Although she regularly discussed this with her caseworker, and despite her possible eligibility for legal stay, the voluntary return' procedure continued and eventually resulted in her removal to Guinea.

Finally, restrictions on the use of detention can also hamper deportation. In the Netherlands, an assistant prosecutor must decide whether an undocumented immigrant may be placed in detention for up to six months. Instead, lighter and less stringent measures are typically imposed, one of which is a duty to report to a government worker every few weeks to discuss the return process. A forty-five-year-old male civil servant responsible for this reporting requirement complained that, according to him, the DT\&V held less control over unauthorised immigrants who 'autonomously' came to his desk than over those in detention, adding that his organisation was 'at risk of losing its clients since they can disappear into illegality once the prospect of return becomes more concrete'.

Taking the abovementioned factors into consideration, variation in non-deportability shapes the options available to government and NGO workers responsible for enforcing 'return'. Indeed, street-level bureaucrats typically estimate if they are faced with a 'promising case for voluntary return' and subsequently adjust their strategies and interviewing techniques. These strategies stem from the so-called 'track-policy' (Sporenbeleid) which the 
Dutch government introduced in 2015 as a measure to deal with what they considered an excessive amount of asylum applications. The new policy's first and second tracks set accelerated procedures for people who fall under the Dublin system (track 1), come from 'safe countries of origin' or have legal status elsewhere in Europe (track 2). These migrants are likely to receive a negative decision on their asylum claim and are ordered to leave the Netherlands within 30 days. Migrants falling into one of these two tracks are often placed in detention quickly after the initial DT\&V interviews, so long as travel documentation is available.

Even these migrants deemed 'easy to deport' are informed about 'voluntary return', however, while being warned of the consequences of non-cooperation. A forty-twoyear-old female caseworker at the limited-movement facility in Ter Apel explained to us: 'If someone in this category shows a willingness to return voluntarily, we will look at the possibilities and contact IOM or other organisations'. Certain categories of 'easily deportable' migrants were clearly granted more leeway and time than others to arrange for their voluntary return. This was the case with families, elderly migrants and other persons classified as particularly vulnerable. The case of a sick, elderly woman from Georgia, interviewed by a thirty-one-year-old female caseworker during our fieldwork, highlighted this practice. Even though the Georgian woman originated from a safe country of origin and a laissez-passer was already available to the DT\&V, the caseworker commented: 'given that she is severely ill and IOM can provide her with additional money if she wishes to return, I grant her extra time to make the necessary arrangements'. Thus, even some rejected migrants whom return officers thought were good prospects for forcible removal were offered the possibility of returning 'voluntarily'.

\section{Return policy and the Dutch deportation continuum}

Approximately 10,000 unauthorised migrants are repatriated every year from the Netherlands, either forcefully or 'voluntarily' (Ministerie van Veiligheid en Justitie 2017). About 500 government employees work at the organisation responsible for removal, the DT\&V. A large proportion of them are so-called 'caseworkers', whose job is to interview their 'clients', unauthorised immigrants, on a regular basis. The interviews may last from five minutes up to two hours, depending on the complexity of the case, and mainly emphasise the prospect of return. In addition to the DT\&V, the Aliens Police, the Central Organ for the Reception of Asylum Seekers and the Royal Marechaussee also hold important roles in the Dutch 'deportation regime' (De Genova and Peutz 2010) by either tracing undocumented immigrants, managing temporary facilities where they are housed or ensuring their physical departure from the Netherlands.

Next to government caseworkers, an extensive field of civil-society organisations, including volunteers and paid workers, assist undocumented immigrants in legal procedures, acquiring shelter and arranging return. We follow Vandevoordt (2018), Kalir and Wissink (2015) and Lietaert, Broekaert, and Derluyn (2017) in designating as street-level bureaucrats not only government workers, but also certain types of NGO personnel. The latter are in direct contact with undocumented immigrants, exert a high level of discretion and grant access to government programmes, such as sponsored return schemes or the Bed, bad en brood shelter programme. There is great variety in the types of non-governmental organisations, ranging from those that can be regarded as government subcontractors, to those operating in agreement with the state, to organisations 
that oppose and challenge state policies (Kalir and Wissink 2015). Kalir and Wissink (ibid., 2) argue that these two seemingly opposing parties - the government and NGOs - can better be conceptualised as a continuum that is 'underlined by a dominant logic, common categories, shared political subjectivities and pre-agreed lines of political actions'. The DT\&V, NGOs and international organisations indeed often collaborate within 'voluntary return' programmes to 'meet the needs' of 'clients' who have been summoned to leave the Netherlands. These programmes are often carried out through the International Organisation for Migration's (IOM) larger 'Assisted Voluntary Return and Reintegration' scheme, which provide participants with financial and in-kind assistance, ranging from paying for flight tickets to providing for documentation, medical assistance, formal education and funds for 'reintegration' (Ashutosh and Mountz 2011). Additionally, several local NGOs provide training and equipment, officially to encourage returnees to start a business or enhance 'reintegration' in the country of origin.

To explore the deportation continuum and strategies government and NGO workers deploy to incite undocumented immigrants to return to their origin countries, Laura Cleton conducted participant observation and interviews in several Dutch municipalities in the first half of 2017. On the government side of the continuum, she spoke to over thirty government employees working at various locations, including asylum seekers' reception centres, limited-movement facilities, detention centres, family locations and regular offices. On the civil society side of the continuum, actors who participated in the research included both salaried and voluntary workers at eighteen different NGOs. These NGOs were scattered along the spectrum theorised by Kalir and Wissink (2015). The different types of NGOs included in the study covered organisations providing shelter in various municipalities, organisations providing counselling and support for undocumented immigrants in legal procedures and organisations focussing on providing vocational training in preparation for return.

To study street-level bureaucrats' strategies, we used a wide range of methods that included direct and participant observation and formal and informal interviewing. We collected data on strategies of government workers during a total of eleven working days at ten different locations of the DT\&V with various actors. During a typical working day, Laura immersed herself into the government workers' daily routines and informally interviewed them on issues such as strategies, views on deportation and their experiences of executing the tasks of a DT\&V employee. Concurrently, she joined government workers during interviews with undocumented immigrants, canteen lunches and meetings with more senior colleagues. This enabled us to retrieve first-hand observations on interactions with undocumented immigrants as well as discussions among colleagues on various strategies they believed that they should follow when dealing with specific cases. In the NGO sector, Laura conducted eighteen semi-structured in-depth interviews with twenty workers, which ranged from fifty minutes to two and a half hours. These interviews dealt with their daily activities, strategies and approaches towards undocumented immigrants and their views on state return policy.

All informal interviews and observations at the DT\&V were processed into observation reports. The semi-structured interviews with the NGO workers were all recorded and transcribed. All material received the consent of the respondents and approval for usage. When interviews are quoted, no names of individuals or NGO organisations are mentioned. 


\section{Emotional bureaucratic labour}

Street-level migration bureaucrats deploy a range of soft coercive strategies in order to obtain the return of undocumented immigrants. Among those is establishing trust relationships on a personal level (Khosravi 2009; Volkskrant, October 30, 2015). In 2014, the DT\&V introduced a new interviewing method for its employees that recommends bonding with migrants as a core strategy (Dienst Terugkeer en Vertrek, 19 May 2017). Government employees must actively build a connection with their 'clients' and engage with their lives, forming what Khosravi $(2009,45)$ in the Swedish case has called a 'human relationship'. The official DT\&V manual (DT\&V 2015) describes an outright 'game' in which 'some employees use charm, others use humour or provide structure to motivate clients to talk'. In practice, caseworkers often ask about family members in the country of origin, inquire about their 'clients' health conditions, or joke about their language skills ('you speak Dutch very well, you do not need a Farsi translator any longer!'). Moreover, caseworkers ostensibly acknowledge the difficult situation their 'clients' find themselves in and exhibit empathy while listening to the stories they tell.

Processes of managing relations and displaying and regulating emotions have famously been conceptualised by Arlie Hochschild (1983) as 'emotional labour'. Hochschild shows that service workers are expected to regulate their emotions during interactions with customers in accordance with employer expectations. In the case of the bureaucratic labour of migration-related agencies, employees are invited to establish what the DT\&V calls a 'working alliance' (werkalliantie) with their 'clients' as they arrange for their return (Dienst Terugkeer en Vertrek, 19 May, 2017). The DT\&V manual recommends that 'the caseworker apply techniques to steer and influence clients, so as to eventually stimulate the foreigner towards an independent decision to return' (DT\&V 2015, 18, emphasis added; see also Khosravi 2009, 45). This strategy may involve having recourse to a caseworker of the same national origin, following the principle of 'native counselling' (Leerkes, van Os, and Boersema 2017). A fifty-six-year-old female DT\&V employee working at the Schiphol detention centre said that, for her, the central component of interviewing 'clients' entails engaging with their personal stories and looking for leads by which they could be triggered to think about going back to their countries of origin. She did this, for example, by eliciting fond memories of the home country or bringing attention to family members that were left behind there and who the returnee would be able to meet again.

Through this 'working alliance', government workers are encouraged to engage with undocumented immigrants on a deeper level and become acquainted with their hopes and fears. Hochschild (1983) distinguishes between two different types of employee emotional labour. The first, surface acting, involves a 'faking process' through which the expression towards 'clients' is altered, but internal feelings and emotions are left intact, resulting in what Hertoghs (2012) calls 'strategic empathy'. Government workers at the DT\&V perform surface acting when they display compassion towards their 'clients' stories while simultaneously adhering to restrictive state policy. A sixty-two-year-old male DT\&V employee, for example, resorted to surface, tactical empathy in his interview with a Kurdish woman from Iraq. The woman told the civil servant about her sick mother and experiences with human traffickers in Turkey. He nodded and told the woman he understood her situation. Immediately afterwards, however, he explained the process of requesting a laissez-passer at the embassy to send her back to Iraq, since her passport 
was missing. When the woman started crying and claimed that she could not return since her life would be in danger, he did not respond and instead told her: 'I assume this means you do not want to cooperate on return. In that case, I will make a note in your file, since you are violating an obligation stated in Dutch law', knowing that this paved the way for a possible forced return procedure in the future.

In deep acting, by contrast, employees themselves alter their internal feelings to align more with expectations, which in the end might produce more genuine emotional displays. Contrary to classic service-sector companies analysed by Hochschild, agencies in the deportation continuum are not primarily at the service of their 'clients'. Yet, DT\&V guidelines indicate that, should the caseworker display 'openness and affection to emphatically show involvement with the client' $(2015,19)$, bonding will result in 'true goodwill to work with the foreigner'. When the abovementioned DT\&V employee at the Schiphol detention centre gave an overview of her 'clients', she almost exclusively called them 'schatjes' (darlings), said she often exchanged her personal phone number with them and that she used her spare time to 'read about [their] cultures to better understand why they come to the Netherlands'. Other caseworkers often made references to their own lives during DT\&V interviews 'to, on the one hand, show that I talk about my own experiences and share personal stories, but also to increase [my client's] doubts about staying by evoking the prospect of being reunited with her husband [in her country of origin]' (forty-two-year-old female DT\&V employee).

Whether acting remains the 'surface' kind or turns 'deep' varies greatly across individuals and situations and is not easy to determine (see also Vandevoordt 2018). At the DT\&V, deep acting may require employees to convince themselves that their 'clients' would be safe if returned to their origin countries. In many ways, it requires believing in the original assessment made by the Dutch government, so that emotional bonding with 'clients' never comes into contradiction with their employer's exclusionary policy objective (Kalir and Wissink 2015). By contrast, NGO personnel generally have more leeway to present options that are not bound by return, so that in their case deep acting does not require believing that the initial government decision is well founded. For NGOs that are heavily funded by the Dutch government, however, deep acting might be as ideologically demanding as for DT\&V workers, since their funding depends on the effective removal of rejected migrants.

In other cases of deep acting, bonding with 'clients' may create tension with government goals and lead return agents to start doubting whether they may or may not be doing the right thing. In their study of Swedish immigration detention centres, Puthoopparambil, Ahlberg, and Bjerneld (2015) analysed this conflict between one's feelings and the established rules and protocols in terms of emotive dissonance. In our fieldwork, for instance, a male government employee in his late fifties working at a family location explained that his 'working alliance' with families and underage children has turned him from a 'rechtse rakker' (right-wing conservative) to a 'softie', potentially at odd with his organisation. He mentioned that 'after twenty-six interviews with the same client, a relationship inevitably starts growing and it often gets very personal as well. That is how I would describe the relationships I have with my clients: involved and personal'. Due to these 'personal' relationships, DT\&V caseworkers sometimes assist in regularisation efforts made by NGOs in favour of the migrant or may question whether the immigration services (IND) really made a 'correct' and 'humane' decision in rejecting 
their application. In order to suppress these feelings, government workers must convince themselves that it is 'not their job' as DT\&V employees to judge the credibility of other agencies in the Dutch government. As we will see, they may also emphasise the individual responsibility 'clients' have for their own fate.

Emotional labour does not stop at the door of the interview room, however, nor is it limited to dyadic bureaucrat-migrant relationships. Indeed, it is not only caseworkers and their 'clients' who are addressed through these interviews: the broader public is also convoked in the social construction of voluntary return. Through a set of audio-visual material available on DT\&V and some NGO websites, bureaucratic labour hence expands into public emotional labour, through which readers and watchers are informed about procedures and methods deployed by caseworkers to obtain 'voluntary' return. These materials consist of documentaries, explanatory videos, collections of stories on day-to-day experiences and newspaper articles introducing interviewing techniques. The involvement of the wider public in emotional labour is thus part and parcel of voluntary return schemes.

\section{We report: providing 'honest' information}

One of the key recommendations for the establishment of a 'working alliance' and the eventual construction of a 'voluntary return' decision is to provide rejected migrants with 'honest' information about their rights and the regulations in place in the Netherlands. Legal procedures are often complicated and while most undocumented immigrants have attorneys, both NGO and government workers spend a lot of time discussing the different procedures and possible routes with their 'clients' as well (DT\&V 2015).

Return agents typically have a double agenda in 'explaining' these procedures, as they also use interviews as an opportunity to have undocumented immigrants contemplate return. Government officers frequently use sentences such as: 'Have you already been thinking about what you are going to do if your appeal is declined?' or 'If you do not leave the Netherlands within twenty-eight days after your appeal is declined, you will be in the Netherlands illegally: is that what you want?'. 'We tell them that they should understand that the bed, bad, brood is not forever, and ask them what they themselves are doing to shape their own future' explained a twenty-two-year-old female NGO worker. 'Information' and threat are often intertwined. Two civil servants said that they do not hesitate to tell their 'clients' that they will soon be put in detention or deported. By doing this, they hope that their 'clients' will 'take matters in their own hands' and envisage returning. 'If you do not come up with a plan B, in four weeks, we will book a flight to Kabul for you and you and your family will leave forcefully', one of them warned during an interview with a couple from Afghanistan with two children, 'is that what you want?'.

The very prospect of legalisation may ironically be deployed as a strategy to encourage voluntary return as a pre-condition for new entry through legal routes. During one observed interview, a fifty-six-year-old female DT\&V employee kept encouraging one of her 'clients' to continue the process of family reunification with his Dutch wife and emphasised the need for him to return to Morocco to apply for an entry visa. She did not go into detail about the requirements and practicalities of the new legal procedure when she talked to him. She later clarified that in the end, our goal is to return people to their country of origin. It does not matter to me that, if he... once he is back in 
Morocco ... applies for a new visa and possibly comes back to the Netherlands. My goal is reached, and if he is eligible for legal stay in the Netherlands, he has the right to do so'.

Most often, providing 'honest' information involves inventorying obstacles and other sources of reluctance that stand in the way of returning. Promising a sum of money convinces some rejected immigrants to consent to departure. Others prefer to be able to finish an education they started, get business training or receive in-kind assistance (Koch 2014; Lietaert, Broekaert, and Derluyn 2017; Collyer 2018). Some government workers research possible job opportunities back in countries of origin. Others recalled printing out documents for new procedures after office hours. Others never do anything extra, however, since '[undocumented immigrants] are not meant to be in the Netherlands anyway' (male DT\&V employee in his forties).

Despite these behavioural differences, all government workers and NGO personnel emphasise undocumented immigrants' decision-making power and 'responsibility for their own future'. This is most clearly visible in so-called 'empowerment trajectories' offered by NGOs, that 'try to ensure that rejected migrants take back control of their own lives and start deciding what is best for them' (twenty-eight-year-old female NGO worker). The DT\&V manual also provides plenty of cues that signal the importance of interpellating the 'client's' agentic power. According to the principles laid out in the DT\&V manual, caseworkers preferably are to be thought of as 'coaches' who provide moral support and underscore the importance of an independent decision (DT\&V $2015,51)$. In a return interview described in the Dutch press, one DT\&V agent addressed a 'client' by proclaiming: 'together, we can clear all the obstacles that stand in the way of return, but you are the one making the change' (De Correspondent, 17 March 2014). The next section examines the implications of invoking 'choice' and 'agency' in the service of the institutionally predefined objective of return.

\section{You decide: choice and agency}

Indeed, central to soft-power strategies to ensure the departure of rejected immigrants is the emphasis on agency. Two civil servants interviewed together claimed that providing different options to their 'clients' and underscoring the choices they have at their disposal makes 'voluntary' return more likely. In their interactions with migrants, they lay out the different pathways their 'clients' can follow, although the range of choices is bounded by the latter's formal obligation to leave the Netherlands. Once the various options are on the table, they explain, it is up to the 'client' to 'decide' what his or her future will look like and how return will take place. In a meeting with a twenty-year-old Albanian man, a forty-one-year-old male civil servant warns: 'either you cooperate with us and we will make sure that you can leave for Albania voluntarily ... but if you disappear and choose to live with your aunt illegally, you risk being arrested and forcefully deported'.

Commenting on an analogous process in the Swedish deportation regime, Khosravi $(2009,46)$ describes how this 'social conversation gives an illusory sense of power and self-determination'. In the Dutch case as well, return officers repeatedly present undocumented immigrants as being in charge of their own future and emphasise their decisionmaking power. During fieldwork, a thirty-seven-year-old senior male DT\&V employee interviewed a man from Myanmar who expressed reluctance to go back to his country, 
but defeatedly said that he would comply with what the DT\&V tells him to do. The civil servant then answered that 'it does not matter what the DT\&V wants you to do, but what you yourself want to do, since you are the one making decisions'. Another female DT\&V employee interviewed a nineteen-year-old Moroccan man who told her that he felt like he kept going around in circles, and that he had no other option than to stay in the Netherlands, since he has a duty to care for his mother back in Morocco. She visualised this endless circle on a piece of paper and told him: 'you are running around like this [in circles] right now, but until you make an effort and decide to break away [pencil leaving the circle] you will stay stuck where you are now. You need to think about what you want'.

From the start, however, it is clear to state employees that the ultimate goal is to govern 'clients' toward return and that the only two real options are 'voluntary return' or deportation (Koch 2014; DT\&V 2015; Walker 2018), delineating what Lietaert (2016) calls 'constrained choice'. As a DT\&V caseworker also suggests: 'We are strict and helpful at the same time. The message they get is: you need to return, and how can we assist you with that?' (Volkskrant, April 15, 2014, emphasis added). In the United Kingdom, this discourse on free choice has become even more restrictive as, since 2014, the Home Office has removed the option of leaving 'voluntarily' from detention centres. Whereas in the Netherlands, 'voluntary return' can take place at any time during the return procedure, the Home Office recently declared that 'AVR [Assisted Voluntary Return] is not a lastminute alternative to removal and should be a considered decision': it thus must happen prior to detention (quoted in Walker 2018, 6, emphasis added). If rejected migrants refuse to take 'responsibility for their own fate' and make a 'voluntary' request prior to being detained, they are seen as 'non-compliant', 'illegal' and 'undeserving' of privileges such as 'voluntary return' (Walker 2018, 8). In Belgium too, the period during which migrants are allowed to apply for AVR has become shorter and there are now more benefits for those who decide to return early on in the procedure (Lietaert, Broekaert, and Derluyn 2017). Rejected migrants therefore have to want to return 'voluntarily', and they must prove it: to varying degrees, this paradoxical logic of forced choice, which unmasks the disciplinary nature of 'freedom' as a government tool by bringing it to its extreme, seems to have become a central feature of European migration regimes. Such practices are also at play in the Netherlands, not on paper or through restricted access to voluntary return programmes, but through the ritualistic performance of 'agency' in return conversations, where migrants are required to express their choice as a result of their own decision power. Hence, choice is not just 'forced' through limited options, but also because migrants have literally no choice but to choose.

Ultimately, the routine invocation of choice also reminds the 'client' of the violent set of unequal domestic and international power relations that generates the situation of urgently 'having to choose', while naturalising these power relations as undebatable. Repeatedly summoning migrants to express their choice and confirm whether they 'really' want to stay in the Netherlands is hence an integral part of the ritual construction of their spatial illegitimacy and out-of-placeness.

\section{Conclusion}

Based on qualitative interviews and ethnographic observation in the Dutch deportation continuum, this article details the techniques return agents and agencies have developed 
to obtain the relocation of rejected migrants to their purported countries of origin while having this departure interpreted as 'voluntary'.

Of great importance during return interviews was the emphasis placed on 'agency' and 'free choice'. Although many scholars have rightly pointed out that 'voluntary return' is, in fact, far from voluntary (Webber 2011; Koch 2014; Kalir 2017; Lietaert, Broekaert, and Derluyn 2017; Vandevoordt 2018), this paper was specifically interested in the institutional and interactional processes through which 'voluntariness' is socially constructed and becomes 'real in its consequences' (Thomas 1928). In particular, we paid attention to procedures by which return agents seek to instil in their 'clients' a sense of being in control over their own lives and of making independent decisions. We analysed these concerns in the spirit of Foucault's lectures on governmentality, arguing that this specific mode of governance through freedom extends to the deportation continuum and thus does not stop at solely regulating citizens. However, governing through freedom implies having to construct individual decisions as 'free'. This article showed that return interviews thus functioned as heavily scripted 'rituals of freedom' involving the forced performance of agency by migrants. Interestingly, the function of those rituals in the deportation process does not seem to be so much that of imposing the actual belief in freedom, in a psychological sense, as that of installing free choice as the dominant definition of the situation. Whether migrants actually believe in the ritual appears to be of secondary importance, as the truth it imposes is not located in individual minds but in the interaction order and the migration regime that structures it.

One might think that this bureaucratic insistence on 'voluntary return' only occurs in cases where deportation is deemed outright impossible and is thus but a way of making a virtue out of a necessity. However, as we saw, in the Netherlands the 'voluntary' option is also offered to deportable migrants, at least initially - the forcible removal procedure is only initiated once they refuse. Indeed, the DT\&V instructs its employees that it is 'worth the effort to motivate every foreigner to cooperate' since this 'can strongly contribute to a dignified, thoughtful and timely return' (2015, 36, emphasis added). Of course, even when available, coercion is generally resource-intensive, risks unleashing public opposition and is also often constitutionally restrained. But practical concerns and cost-effectiveness are only part of the explanation and governmental insistence on 'voluntariness' also illuminates the centrality of freedom as a mode of legitimate government in liberal states (cf. Gibney 2008), even in the presence of more coercive alternatives, and however fictitious that freedom turns out to be. More comparative research would be needed to determine whether the disciplinary effects of the invocation of 'freedom' in the case of voluntary return stand in contrast to more genuine and empowering deployments of the language of freedom when applied to full citizens. Or, on the contrary, whether the symbolic violence of freedom in the deportation apparatus points to a deeper and more inconvenient truth about broader citizenship technologies, whomever they apply to. At a minimum, by making free choice the new emblem of better government, neoliberal governmentality has become so pervasive that it now imposes its rhetoric even on ostensibly illiberal situations, ultimately turning the latter into dubious masquerades of freedom.

\section{Note}

1. The English edition erroneously writes 'the specific limits to this freedom'. We fixed the sentence based on the French edition, which, for this paragraph, is an exact verbatim of the 
original recording of Foucault's French-language lecture given at the Collège de France on April 5th, 1978: 'L'intégration des libertés et des limites propres à cette liberté à l'intérieur du champ de la pratique gouvernementale, c'est maintenant devenu un impératif.

\section{Acknowledgements}

We would like to thank Celine Cantat for her generous comments on an earlier version of this paper, presented at the ECPR-SGEU Conference at Science Po, Paris, 13-15 June 2018. We moreover benefited from Madeleine Arenivar and Hannah Goldwyn Simpkins' readings of a draft version of this paper. Finally, we would like to express our gratitude to three anonymous reviewers and JEMS editors for their detailed and thought-provoking comments.

\section{Disclosure statement}

No potential conflict of interest was reported by the authors.

\section{References}

Andrijasevic, Rutvica, and William Walters. 2010. "The International Organization for Migration and the International Government of Borders." Environment and Planning D: Society and Space 28 (6): 977-999.

Ashutosh, Ishan, and Alison Mountz. 2011. "Migration Management for the Benefit of Whom? Interrogating the Work of the International Organization for Migration." Citizenship Studies 15 (1): 21-38.

Broeders, Dennis. 2010. "Return to Sender? Administrative Detention of Irregular Migrants in Germany and the Netherlands." Punishment \& Society 12 (2): 169-186.

Castañeda, Heide. 2008. "Paternity for Sale: Anxieties Over 'Demographic Theft' and Undocumented Migrant Reproduction in Germany.” Medical Anthropology Quarterly 22 (4): 340-359.

Chauvin, Sébastien, and Blanca Garcés-Mascareñas. 2012. "Beyond Informal Citizenship: The New Moral Economy of Migrant Illegality.” International Political Sociology 6 (3): 241-259.

Collyer, Michael. 2012. "Deportation and the Micropolitics of Exclusion: The Rise of Removals From the UK to Sri Lanka." Geopolitics 17 (2): 276-292.

Collyer, Michael. 2018. "Paying to Go: Deportability as Development." In After Deportation: Ethnographic Perspectives, edited by Shahram Khosravi, 105-125. London: Palgrave Macmillan.

Cruishank, Barbara. 1999. The Will to Empower: Democratic Citizens and Other Subjects. New York: Cornell University Press.

De Genova, Nicholas P. 2002. "Migrant Illegality and Deportability in Everyday Life." Annual Review of Anthropology 31 (1): 419-447.

De Genova, Nicholas P., and Nathalie Peutz. 2010. The Deportation Regime: Sovereignty, Space and the Freedom of Movement. Durham: Duke University Press.

Dienst Terugkeer en Vertrek (DT\&V). 2015. Methodische Handleiding DTఓV: Werken in Gedwongen Kader. Ministerie van Veiligheid en Justitie: Den Haag.

Dubois, Vincent. 2014. "The State, Legal Rigor, and the Poor: The Daily Practice of Welfare Control." Social Analysis 58 (3): 38-55.

Ellerman, Antje. 2010. "Undocumented Migrants and Resistance in the Liberal State." Politics \& Society 38 (3): 408-429.

Fatovic, Clement, and Benjamin A. Kleinerman. 2013. "Introduction: Extra-Legal Measures and the Problem of Legitimacy." In Extra-legal Power and Legitimacy: Perspectives on Prerogative, edited by Clement Fatovic, and Benjamin A. Kleinerman, 1-23. Oxford: Oxford University Press.

Foucault, Michel. 2007. Security, Territory, Population: Lectures at the College de France, 1977-78. London: Palgrave Macmillan. 
Gibney, Matthew J. 2008. "Asylum and the Expansion of Deportation in the United Kingdom.” Government and Opposition 43 (2): 146-167.

Hertoghs, Maja. 2012. "Emotions and the Legal Construction of Truth: an Ethnographic Study of the Dutch Asylum Procedure." (Master's Thesis). University of Amsterdam.

Hochschild, Arlie. 1983. The Managed Heart: Commercialization of Human Feeling. Berkeley: University of California Press.

Inda, Jonathan X. 2005. Targeting Immigrants: Government, Technology, and Ethics. Malden, MA: Blackwell.

Kalir, Barak. 2017. "Between 'Voluntary' Return Programs and Soft Deportation. Sending Vulnerable Migrants in Spain Back 'Home'." In Return Migration and Psychosocial Wellbeing: Discourses, Policy-Making and Outcomes for Migrants and Their Families, edited by Zana Vathi, and Russel King, 56-71. Abingdon: Routledge.

Kalir, Barak, and Lieke Wissink. 2015. "The Deportation Continuum: Convergences Between State Agents and NGO Workers in the Dutch Deportation Field." Citizenship Studies 20 (1): 34-49.

Kassin, Saul M., and Karlyn R. McNall. 1991. "Police Interrogations and Confessions: Communication Promises and Threats by Pragmatic Implication." Law and Human Behavior 15 (1): 233-251.

Khosravi, Shahram. 2009. "Sweden: Detention and Deportation of Asylum Seekers." Race \& Class 50 (4): 38-50.

Koch, Anne. 2014. "The Politics and Discourse of Migrant Return: The Role of UNHCR and IOM in the Governance of Return." Journal of Ethnic and Migration Studies 40 (6): 905-923.

Leerkes, Arjen, Rianne van Os, and Eline Boersema. 2017. "What Drives 'Soft Deportation'? Understanding the Rise in Assisted Voluntary Return among Rejected Asylum Seekers in the Netherlands." Population, Space and Place 23 (8): 1-11.

Leo, Richard A. 1992. "From Coercion to Deception: the Changing Nature of Police Interrogation in America." Crime, Law and Social Change 18 (1): 35-59.

Leo, Richard A. 1996. "Inside the Interrogation Room." The Journal of Criminal Law \& Criminology 86 (2): 266-303.

Lietaert, Ine. 2016. "Perspectives on Return Migration: a Multi-Sited, Longitudinal Study on the Return Processes of Armenian and Georgian Migrants." (PhD Dissertation). University of Ghent.

Lietaert, Ine, Eric Broekaert, and Ilse Derluyn. 2017. "From Social Instrument to Migration Management Tool: Assisted Voluntary Return Programmes - The Case of Belgium.” Social Policy \& Administration 51 (7): 961-980.

Lipsky, Michael. [1980] 2010. Street-level Bureaucracy: Dilemmas of the Individual in Public Services. New York: Russel Sage Foundation.

Ministerie van Veiligheid en Justitie. 2017. Rapportage Vreemdelingenketen. Periode JanuariDecember 2016. Ministerie van Veiligheid en Justitie: Den Haag.

Nye, Joseph S. 2004. "Soft Power and American Foreign Policy." Political Science Quarterly 119 (2): 255-270.

Ofshe, Richard J., and Richard A. Leo. 1997. "The Decision to Confess Falsely: Rational Choice and Irrational Action.” Denver University Law Review 74 (4): 979-1122.

Paoletti, Emanuela. 2010. "Deportation, Non-Deportability and Ideas of Membership". Working Paper Series No. 65. Oxford: Refugee Studies Centre.

Puthoopparambil, Soorej J., Beth M. Ahlberg, and Magdalena Bjerneld. 2015. "It is a Thin Line to Walk on': Challenges of Staff Working at Swedish Immigration Detention Centres." International Journal of Qualitative Studies on Health and Well-Being 10 (1): 1-11.

Rose, Nikolas. 1999. Powers of Freedom: Reframing Political Thought. Cambridge: Cambridge University Press.

Rosenberger, Sieglinde. 2014. "After the Deportation Gap: Non-Removed Persons and Their Pathways to Social Rights". Paper Presented at the European Social Science History Conference, Vienna, April 23-26.

Shuy, Roger W. 1998. The Language of Confession, Interrogation and Deception. Thousand Oaks: Sage Publications.

Thomas, William. 1928. The Child in America: Behaviour Problems and Programs. New York: Knopf. 
Thomas, George III, and Richard A. Leo. 2012. Confessions of Guilt: From Torture to Miranda and Beyond. Oxford: Oxford University Press.

Ticktin, Miriam. 2006. "Where Ethics and Politics Meet: The Violence of Humanitarianism in France." American Ethnologist 33 (1): 33-49.

Van der Leun, Joanne. 2006. "Excluding Illegal Migrants in The Netherlands: Between National Policies and Local Implementation." West European Politics 29 (2): 3010-326.

Vandevoordt, Robin. 2018. "Judgement and Ambivalence in Migration Work: On the (Dis)Appearance of Dilemmas in Assisting Voluntary Return.” Sociology 52 (2): 282-297.

Walker, Sarah. 2018. "Detention and its Discontents: Punishment and Compliance Within the U.K. Detention Estate Through the Lens of the Withdrawal of Assisted Voluntary Return." Journal of Ethnic and Migration Studies, doi:10.1080/1369183X.2018.1443805.

Webber, Frances. 2011. “How Voluntary are Voluntary Returns?” Race \& Class 52 (4): 98-107. 